\title{
Animals as Sentinels for Human Lead Exposure: A Case Report
}

\author{
Karyn Bischoff • Heather Priest • Amy Mount-Long
}

Published online: 18 March 2010

(C) American College of Medical Toxicology 2010

\begin{abstract}
Because human and nonhuman animals often share the same environment, there is potential concurrent exposure to toxicants. As a result, domestic animals can be used as sentinels for exposure of people to these agents. Here we present a case illustrating exposure of both humans and domestic animals to lead contamination in their environments. This case study occurred at a farm where cattle deaths were determined to have been caused by lead poisoning based on elevated postmortem tissue lead concentrations. Elevated blood lead concentrations were detected in the remaining cattle, a dog, a cat, and a pregnant woman $(37.3 \mu \mathrm{g} / \mathrm{dL})$ living on the farm. The range of blood lead concentrations in the domestic animals was 8.42 (cat) to $85.41 \mu \mathrm{g} / \mathrm{dL}$ (calf), although clinical signs of lead poisoning were not apparent in these animals. Further testing revealed the most likely source for lead exposure to be paint in the barn and home.
\end{abstract}

Testing for case study number 2 was funded by the United States Department of Agriculture Cooperative Research, Education, and Extension Service.

The abstract has been submitted for consideration for the Spring Symposium for the Center for Biodiversity and Conservation at the American Museum of Natural History.

\section{K. Bischoff $(\bowtie)$}

Department of Population Medicine and Diagnostic Sciences, College of Veterinary Medicine, Cornell University,

P. O. Box 5786, Ithaca, NY 13081, USA

e-mail: KLB72@cornell.edu

H. Priest

Department of Population Medicine and Diagnostic Sciences, College of Veterinary Medicine, Cornell University,

S1-050 Schurman Hall, Ithaca, NY 14853, USA

A. Mount-Long

Haskell Valley Veterinary Clinic,

2148 Haskell Road,

Olean, NY 14760, USA
Household dogs and cats have been used as sentinels for lead poisoning in humans, but cattle may also act as a sentinel species for environmental lead contamination.

Keywords Lead poisoning $\cdot$ Sentinel $\cdot$ Cattle $\cdot$ Dogs

\section{Introduction}

Historically, domestic animals have been used as sentinels for toxic and infectious diseases $[1,2]$ and more specifically are known to play a critical role in defining human lead exposure as both sentinels and, in the case of food animals, sources of the toxicant [3-5]. The ability of animals to provide this early warning relies on communication between medical and veterinary medical communities. Though acute lead poisoning is relatively rare in children [6], chronic childhood lead poisoning is described as one of the most common environmentally caused diseases in children of the USA and developing world [7]. This is due to the continued presence of lead in the environment from sources that predate current lead use regulations in the developed world [8-11] and the lack of implementation of regulations against the use of lead in developing countries [12-14]. Lead poisoning remains common in animal agriculture and is the most common heavy metal toxicosis in cattle [15]. Once one of the most commonly reported toxicoses in small animals [16], lead poisoning has declined in incidence due primarily to the regulated reduction of lead in products such as paint, solder, and gasoline $[9,10]$.

Here we present a case study involving a farm in which lead paint contaminated the house and barn. Of the animals tested, measurable concentrations of lead were documented in seven of seven cattle, one of one dog, and one of one cat, but not in three horses or a goat residing on the farm. One human, a pregnant woman living on the farm, had elevated blood lead concentrations. 


\section{Case Study}

A liver sample from a 2-year-old Angus heifer (Cow 1) was submitted for lead analysis in February 2008. The heifer had a history described as 2 days of "neurological signs" before death. Hepatic lead analysis was performed using inductively coupled plasma-atomic emissions (ICP-AE) spectrometry (Perkin-Elmer, Optima DV2100). The liver lead concentration was $23.1 \mathrm{mg} / \mathrm{kg}$ dry matter. Lead toxicosis in cattle has been associated with liver or kidney lead concentrations $\geq 5 \mathrm{mg} / \mathrm{kg}$ wet weight, or more than or equal to approximately $20 \mathrm{mg} / \mathrm{kg}$ dry matter (assuming that fresh tissue is 75\% water) [17]. A diagnosis of lead poisoning was made based on tissue analysis and clinical signs. The owner of the farm, a pregnant veterinarian, subsequently had her blood tested for lead. Her blood lead concentrations were $37.3 \mu \mathrm{g} / \mathrm{dL}$ on February $18,20.6 \mu \mathrm{g} / \mathrm{dL}$ on March 3, and $20.6 \mu \mathrm{g} / \mathrm{dL}$ on May 25 (reference range of 0.0 to $9.9 \mu \mathrm{g} / \mathrm{dL})$. The baby was born on May 26, apparently healthy, with a blood lead concentration at birth of $14.0 \mu \mathrm{g} / \mathrm{dL}$. One man lived in the home, but spent relatively little time there compared to the woman. His blood lead concentration was not significantly elevated.

The farm had a single barn with a pen housing the cattle and another pen for three horses. The cattle also had access to a small outdoor paddock, and the horses had access to a large pasture. Two cats roamed freely on the premises. A small pen within the barn was used to house a goat, who also roamed freely when the owners were present. The farmhouse was located across a narrow driveway from the barn and, in addition to the human inhabitants, housed two dogs, which were kept indoors most of the day and allowed access to the barn only when the owners were present. None of the surviving animals developed clinical signs of lead poisoning.

An investigation to determine the source(s) and extent of the lead contamination was conducted and involved collection and analysis of blood, milk, and tissues from animals on the farm, as well as environmental sampling and testing for lead contamination. Blood and/or tissue samples were collected from two additional cows that died, two cows recently post-partum (within 10 days of calving), their two calves, three horses, one goat, one cat, and one dog. Tissue lead concentrations were determined using ICP-AE, and blood and milk samples were analyzed using graphite furnace atomic absorption spectronomy (GF-AA). The results of this testing are summarized in Table 1. Environmental samples included paint chips from the barn and home, water from various sources, and scrapings from a work bench and two areas of the barn floor. Liquid samples were analyzed via GF-AA and solid samples by ICP-AE. The results are summarized in Table 2.

\section{Discussion}

This case illustrates exposure of both humans and nonhuman animals to lead contamination in their environments and lends further support to previous reports of the use of domestic animals as sentinels for toxic disease in humans. Domestic animals have acted as sentinels for lead exposure in humans [3-5], and a recent report of lead toxicosis in two cats raised concern and prompted testing of their pregnant owner, who was subsequently found to have potentially harmful blood lead concentrations in the absence of clinical signs [8]. However, a survey of children in an area where lead poisoning was present in cattle did not find what its authors considered to be significant blood lead concentrations in the children (mean blood lead concentration $=2.6 \mu \mathrm{g} / \mathrm{dL}$ ) [6]. The major source of contamination for animals on the farm in this case study was lead paint. Five cows, two calves, a dog, a cat, and a person living on the property had elevated blood lead concentrations, and one cow and one calf had blood lead concentrations above $30 \mu \mathrm{g} / \mathrm{dL}$, a concentration that has been associated with clinical toxicosis in domestic animals [17]. The paint used on the outside of the home contained $14.4 \%$ lead, and cattle had access to paint containing $57.5 \%$ lead. There were two different sources of exposure on the farm: lead paint on the barn for the cattle (and cat) and lead paint on the house for the human (and dog). Although there was no direct evidence of ingestion of paint by cattle in the barn, the paint was chipped and peeling. Paint chips were most likely ingested directly from the walls and doors of the barn, though there was also contamination of the debris on the floor of the cattle area $(643 \mathrm{mg} / \mathrm{kg})$. The cat probably ingested lead from the floor and barn dust that accumulated on his coat through grooming behavior. It is interesting to note that the horses and goat remained unaffected. The paint in the area of the barn that the horses had access to contained only $14.6-74.6 \mathrm{mg} / \mathrm{kg}$ lead, and the paint inside the barn that the goat had access to most of the time contained $445 \mathrm{mg} / \mathrm{kg}$ lead.

The house was undergoing renovation, and paint removal was the most likely source of access to lead for the human and dog via inhalation and ingestion of lead paint dust (through grooming in the dog and hand-to-mouth contact or eating from contaminated surfaces in the human). Although the sources of lead paint were different between the cattle and cat and the human and dog, it was the presence of lead poisoning in the cattle that caused the owner to check her own blood lead concentration and to test the paint in the barn and home as possible sources of lead.

Diagnosis of lead poisoning in household pets has been used to indicate the need for testing of people in the home, as noted previously. A study from Illinois determined that 
Table 1 Blood and tissue lead concentrations in farm animals

\begin{tabular}{lllll}
\hline Animal identification & Blood lead $(\mu \mathrm{g} / \mathrm{dL})$ & Milk lead $(\mathrm{mg} / \mathrm{L})$ & Tissue & Tissue lead $(\mathrm{mg} / \mathrm{kgdm})$ \\
\hline Calf 1 & 18.56 & & & \\
Calf 2 & 85.21 & & Liver & 23.09 \\
Cow 1 & & Kidney & 2.68 \\
Cow 2 & & Kidney & 5.41 \\
Cow 3 & & & Liver & 4.62 \\
& & & Placenta & 1.53 \\
Cow 4 & & & \\
Cow 5 & 44.75 & 0.115 & \\
Horse 1 & 15.04 & 0.273 & \\
Horse 2 & ND & & \\
Horse 3 & ND & & \\
Goat & ND & & \\
Cat & ND & & \\
Dog & 8.42 & & \\
\hline
\end{tabular}

high blood lead concentrations in a family dog resulted in a 6-fold increase in probability that at least one child in the household would have an elevated blood lead concentration [5]. Dogs tend to have significantly higher blood lead concentrations than children in the home, usually by a factor of 2 to 4 [7, 18].

Preventing lead exposure in small children is of particular importance because this is a period of nervous system development [6]. The Center for Disease Control (CDC) set the level of concern for blood lead in children at $10 \mu \mathrm{g} / \mathrm{dL}$, but adverse effects are possible at lower concentrations. Researchers have found IQ deficits and behavior and developmental effects with blood lead concentrations of $10 \mu \mathrm{g} / \mathrm{dL}$ in children [14].
Blood lead concentrations of $30 \mu \mathrm{g} / \mathrm{dL}$ may be associated with clinical lead poisoning in domestic species, as noted previously [17]. Blood lead concentrations in the farm animals ranged from 8.4 (cat) to $85.4 \mu \mathrm{g} / \mathrm{dL}$ (calf). None of these animals displayed clinical signs of lead poisoning, although the earlier death of a cow drew attention to the problem of lead contamination on the farm. Similar variations in blood lead concentrations in the absence of clinical signs have been previously reported, although subtle signs such as depression or change in behavior might have been overlooked [13, 19].

Typical clinical signs of lead toxicosis vary between humans and other mammalian species. Signs in humans include nervous system effects such as lead encephalopathy,
Table 2 Lead concentrations from environmental samples given on a dry matter basis

$N D$ not detected (detection limit of $0.01 \mathrm{mg} / \mathrm{kg}$ )

\begin{tabular}{lll}
\hline Sample type & Location & Lead $(\mathrm{mg} / \mathrm{kg})$ \\
\hline Paint & Barn, cattle access & 575,000 \\
Paint & North wall, no animal access & 130,000 \\
Paint & Door 1, horse access & 14.6 \\
Paint & Door 2, horse access & 74.6 \\
Paint & Inside barn, goat access & 445 \\
Paint & House & 144,000 \\
Soil & Cow paddock & 42.8 \\
Soil & Horse pasture & 39.0 \\
Soil & House, under porch & 27.0 \\
Floor scrape & Cow stall & 643 \\
Floor scrape & Horse stall & 149 \\
Wood chips & Workbench in barn, no livestock access & 447 \\
Water & Cattle tank & ND \\
Water & Horse tank & ND \\
Water & Barn spigot & ND \\
Water & Creek & ND \\
\hline
\end{tabular}


cognitive defects, developmental defects, and behavioral changes, as well as anemia $[6,20,21]$. Clinical signs in young cattle are similar to those in humans [22]. The classic presentation for mature cattle includes ataxia, blindness, hypersalivation, and coma, although anemia has also been reported [22, 23]. In contrast to the central nervous system signs seen in humans and cattle, horses more commonly present with peripheral neuropathies [17]. Gastrointestinal signs such as vomiting, anorexia, and diarrhea usually predominate in adult dogs and cats, while neurologic signs are more common in puppies [9, 24, 25].

Absorption of lead is dependent on the form of lead ingested and on the route of exposure. Once absorbed from the gastrointestinal tract, most of the lead is bound to red blood cells with the unbound portion being quickly distributed to various organs including liver, kidneys, and brain. Over time, the lead is redistributed to bone, which serves as a long-term storage depot. Excretion occurs via the feces, urine, and milk. Once the lead is depleted from the soft tissues, bone stores are mobilized and excreted. This process results in the slow, multiphasic half-lives of lead. Measurement of the halflife of intravenously administered lead in dogs revealed a triphasic pattern of 12,184 , and 4,591 days [17]. Similarly, the half-life of lead in cattle has been shown to range from 48 to 2,507 days [15]. Since the cattle in this study were destined for beef production, further testing was advised to determine when the blood lead concentration had decreased adequately before slaughter. Testing of meat was also recommended. Although lead was detected in milk from two of the cows, these were beef cattle and not dairy cattle; thus the milk was not used for human consumption. Regulation of the allowable amount of lead in meat and milk varies between states.

In summary, domestic animals have the potential to act as sentinels for toxicant exposure in humans. Companion animals, like cats and dogs, often share the immediate environment of people and have access to the same air, water, and food [6, 26, 27]. Livestock, including cattle, horses, and goats, on the other hand, can have increased exposure to certain environmental toxicants since they live in outdoor environments [22]. The case described here illustrates that animals living in close proximity to humans are susceptible to environmental toxicant exposure. Thus identification of elevated tissue contaminant concentrations or overt toxicosis in domestic animals can provide an early warning to a potential problem in people sharing the same environment. Human food chain contamination must be considered for the affected cattle, since these animals were destined for eventual human consumption. Collaboration between the medical and veterinary medical communities will allow more advantageous use of domestic animals as sentinels [1].
Acknowledgments The authors would like to thank Dr. Belinda Thompson, Dr. Tracy Stokol, Kerry Manzell, Joe Hillebrandt, and Joe Ebel for their generous contributions to this case report.

\section{References}

1. Rabinowitz P, Gordon Z, Chudnov D et al (2006) Animals as sentinels for bioterrorism agents. Emerg Infect Dis 12:647651

2. Glickman LT (1990) Analytical epidemiology in pet populations for environmental risk assessment. In: Sandhu SS, Lower WR, de Serres JF et al (eds) In situ evaluations of biological hazards of environmental pollutants. Plenum, New York, pp 133-143

3. Berny PJ, Cote LM, Buck WB (1995) Can household pets be used as reliable monitors of lead exposure to humans? Sci Tot Environ 172:163-173

4. Ghisleni G, Spagnolo V, Roccabianca P et al (2004) Blood lead levels, clinico-pathological findings and erythrocyte metabolism in dogs from different habitats. Vet Hum Toxicol 46:57-61

5. Thomas CW, Rising JL, Moore JK (1976) Blood lead concentrations of children and dogs from 83 Illinois families. J Am Vet Med Assoc 69:1237-1240

6. Feely E, Garavan C, Kelleher K (2003) Dead cattle, lead and child health. Irish Med J 96:232-234

7. Ostrowski SR (1990) Sentinel animals (dogs) as predictors of childhood exposure to environmental lead contamination: observations on preliminary results. In: Sandhu SS, Lower WR, de Serres JF et al (eds) In situ evaluations of biological hazards of environmental pollutants. Plenum, New York, pp $145-150$

8. Doumouchtsis SK, Martin NS, Robins JB (2006) "Veterinary" diagnosis of lead poisoning in pregnancy. Brit Med J (Clin Res Ed) 333:1302-1303

9. Morgan RV, Moore FM, Pearce LK et al (1991) Clinical and laboratory findings in small companion animals with lead poisoning: 347 cases (1977-1986). J Am Vet Med Assoc 199:98-102

10. Morgan RV (1994) Lead poisoning in small companion animals: an update (1987-1992). Vet Hum Tox 36:18-22

11. Zabka TS, Haulena M, Puschner B et al (2006) Acute lead toxicosis in a harbor seal (Phoca vitulina richardsi) consequent to ingestion of a lead fishing sinker. J Wildl Dis 42:651-657

12. Kalra V, Chitralekha KT, Dua T et al (2003) Blood lead levels and risk factors for lead toxicity in children from schools and an urban slum in Delhi. J Tropic Pediat 49:121-123

13. Swarup D, Patra RC, Dwivedi SK et al (2000) Blood lead and cadmium in dogs from urban India. Vet Hum Toxicol 42:232233

14. Wigg NR (2001) Low-level lead exposure and children. J Paediat Child Health 37:423-425

15. Rumbeiha WK, Braselton WE, Donch D (2001) A retrospective study on the disappearance of blood lead in cattle with accidental lead toxicosis. J Vet Diag Invest 13:373-378

16. Hamir AN (1986) Review of lead poisoning in dogs. Vet Bull 56:1059-1070

17. Gwaltney-Brant S (2004) Lead. In: Plumlee KH (ed) Clinical veterinary toxicology. Mosby, St. Louis, pp 204-210

18. Mañay N, Cousillas AZ, Alvarez C et al (2008) Lead contamination in Uruguay: the "La Teja" neighborhood case. Rev Environ Contam Toxicol 195:93-115

19. Koh TS (1995) Diagnosis of lead poisoning in dogs. Aust Vet J 62:392-394 
20. Bonilla CM, Mauss EA (1988) A community-initiated study of blood lead levels of Nicaraguan children living near a battery factory. Am J Pub Health 88:1843-1845

21. Brown MJ (2007) Interpreting and managing blood lead levels $<10 \mu \mathrm{g} / \mathrm{dL}$ in children and reducing childhood exposure to lead. MMWR 56:1-14, 16

22. Sharding NN, Oehme FW (1973) The use of animal models for comparative studies of lead poisoning. Clin Toxicol 6:419-424

23. Ozmen O, Mor F (2004) Acute lead intoxication in cattle housed in an old battery factory. Vet Hum Toxicol 46:255-256
24. Knecht CD, Crabtree J, Katherman A (1979) Clinical, clinicopathologic, and electroencephalographic features of lead poisoning in dogs. J Am Vet Med Assoc 175:196-201

25. Casteel SW (2006) Lead. In: Peterson ME, Talcott PA (eds) Small animal toxicology, 2nd edn. Elsevier, St Louis, pp 795-805

26. Backer LC, Grindem CB, Corbett WT et al (2001) Pet dogs as sentinels for environmental contamination. Sci Tot Environ 274:161-169

27. Buck WB (1979) Animals as monitors of environmental quality. Vet Hum Toxicol 21:277-284 